\title{
Cytologie bij zangvogels: een nuttige diagnostische tool
}

\author{
Cytology in Passeriformes: a useful diagnostic tool
}

\begin{abstract}
A. Garmyn, M. Verlinden
Vakgroep Pathologie, Bacteriologie en Pluimveeziekten, Faculteit Diergeneeskunde, Universiteit Gent, Salisburylaan 133, B-9820 Merelbeke
\end{abstract}

An.Garmyn@UGent.be

\begin{abstract}
S
AMENVATTING

Ziekteproblemen bij in groep gehouden zangvogels zijn vaak van infectieuze aard. De waargenomen klinische klachten zijn echter dikwijls dezelfde en voornamelijk aspecifiek. Cytologisch onderzoek van de organen na post-mortemonderzoek zijn desgevallend van onschatbare diagnostische waarde. In dit artikel worden de basisprincipes van de cytologische staalnametechniek van organen en de beoordelingswijze van een cytologisch preparaat beschreven. Verder wordt een overzicht gegeven van belangrijke infectieuze aandoeningen bij zangvogels, waarvan met behulp van cytologisch onderzoek een definitieve of waarschijnlijke, etiologische diagnose gesteld kan worden. Bij deze kan dit overzicht een nuttige leidraad zijn voor elke dierenarts met zangvogels in zijn of haar patiëntenbestand.
\end{abstract}

\section{ABSTRACT}

Disease outbreaks in Passeriformes housed in group are often of infectious origin. Clinical signs observed are often similar and non-specific. In these cases, cytology is an invaluable tool for developing a presumptive or definitive diagnosis that can guide disease management decisions within a flock. In the first part of this review, the basic principles of cytological sampling techniques and the evaluation of the cytological findings are described. In the second part, an overview of important infectious diseases in Passeriformes is given, in which cytology may lead to a definitive or presumptive diagnosis.

\section{INLEIDING}

Bij zangvogels die in groep worden gehouden zijn ziekteproblemen dikwijls van infectieuze aard. Klinische klachten die desgevallend worden waargenomen zijn echter vaak dezelfde en aspecifiek. In vele gevallen wordt melding gemaakt van plotse sterfte zonder klinische symptomen of sterfte voorafgegaan door een korte periode van dik zitten, anorexie en vermageren. Af en toe wordt ook dyspneu of afwijkende mest vastgesteld. Wegens de kleine omvang van zangvogels is staalname bij een levend dier vaak beperkt. Wanneer sterfte wordt waargenomen, is post-mortemonderzoek met cytologisch onderzoek van de organen van onschatbare diagnostische waarde. Het morfologisch detail van weefselcellen en vooral van bepaalde infectieuze agentia is bij cytologie vaak duidelijker dan bij histologie. Het is daarom een onmisbare diagnostische tool om bacteriële, parasitaire, gist-, schimmel- en virale infecties aan te tonen. Bovendien is cytologie een snelle, goedkope en eenvoudige techniek die gemakkelijk door de clinicus in praktijk kan gebracht worden en bij een groot deel van deze ziekteproblemen kan leiden tot een definitieve of waarschijnlijkheidsdiagnose. Hierdoor kan snel gestart worden met een gerichte therapie bij de overige zieke vogels in de groep, eventueel in afwachting van verder bacteriologisch, histologisch en PCR-onderzoek.

In het eerste deel van dit artikel worden kort de basisprincipes van de staalnametechniek en de beoordeling van een cytologisch preparaat beschreven. In het tweede deel wordt op basis van de waargenomen ziekte aan de Afdeling voor Pluimvee, Bijzondere Gezelschapsdieren, Wildlevende dieren en Proefdieren van de Faculteit Diergeneeskunde (UGent), een overzicht gegeven van belangrijke infectieuze aandoeningen bij zangvogels, waarvan met behulp van cytologisch onderzoek een definitieve of waarschijn- 
lijke, etiologische diagnose gesteld kan worden. Hierbij wordt elke aandoening geïllustreerd met een karakteristiek cytologiebeeld.

\section{TECHNIEK}

De benodigdheden voor cytologisch onderzoek zijn een schaar of bistouri en pincet, papieren tissues, microscopieglaasjes, dekglaasjes, een snelle bloedkleuring en een microscoop. Hoewel de procedure eenvoudig is, is het nemen van kwalitatief goede stalen van primordiaal belang. Stalen worden het beste genomen van vers gestorven dieren. Wanneer meerdere dieren in een groep zijn aangetast, kan eventueel een ziek dier geëuthanaseerd worden voor postmortemonderzoek. Standaard worden door de auteurs bij post-mortemonderzoek orgaanafdrukken genomen van long, lever, milt en nier. Verder worden uitstrijkjes genomen van de kliermaagmucosa en darminhoud om de aanwezigheid van de pathogene flora te evalueren. Wanneer andere organen macroscopisch afwijkend zijn, kunnen bijkomende afdrukken van deze organen worden genomen.

\section{Staalname}

Het doel van de techniek is een "monolayer" van cellen te verkrijgen, waarbij celbeschadiging minimaal is.

\section{Orgaanafdrukken}

Voor het maken van een orgaanafdruk wordt met een vers ingesneden weefseloppervlakte gestart. Wanneer macroscopisch letsels zichtbaar zijn, bijvoorbeeld necrosehaarden en granulomen, is het aan te raden een staal te nemen doorheen het letsel, met ook intact weefsel op het afdrukpreparaat. Stalen van grote necrosehaarden zijn bijvoorbeeld in het centrum niet diagnostisch; aan de periferie zullen de cellen nog intact zijn. Om contaminatie van het snij-oppervlak te vermijden, is het belangrijk om bij elke staalname proper snijmateriaal (schaar of bistouri) te hanteren. Vervolgens wordt het snij-oppervlak verscheidene malen voorzichtig afgedrukt op een propere papieren doek om overmatig vocht en bloed te verwijderen. Dit is belangrijk aangezien door de aanwezigheid van overmatig perifeer bloed de diagnostische cellen worden verdund en gemaskeerd (Dorrestein, 2008). Vervolgens worden afdrukken gemaakt op een microscopieglaasje. Bij het afdrukken is het belangrijk niet teveel druk op de weefselstukjes uit te oefenen, aangezien dit kan leiden tot het stukdrukken van de weefselcellen. Per orgaan worden verschillende afdrukken gemaakt. Hierbij mogen de verschillende afdrukken elkaar niet overlappen; dit om het verkrijgen van een monolayer niet te verhinderen. Afdrukken van verschillende organen kunnen verzameld worden op één

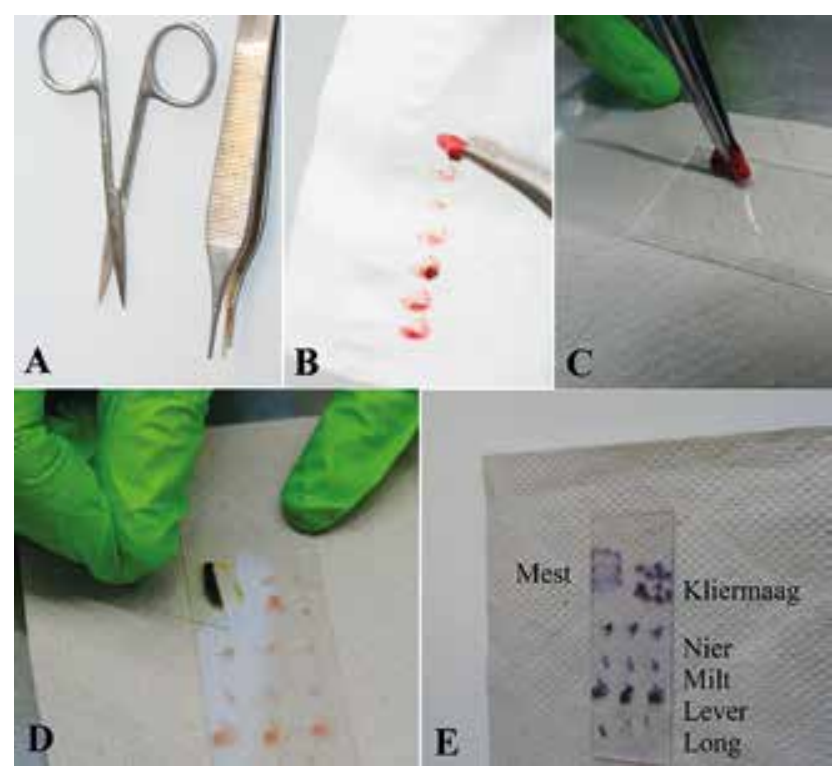

Figuur 1. Staalnametechniek. A. Start met proper materiaal. B. Het snijvlak van het orgaan wordt eerst verscheidene malen voorzichtig afgedrukt op een propere papieren doek om overmatig vocht en bloed te verwijderen. C. Vervolgens worden orgaanafdrukken gemaakt op een microscopieglaasje. Per orgaan worden verschillende afdrukken gemaakt. De afdrukken mogen elkaar niet overlappen. D. Voor het maken van een direct uitstrijkje wordt de mestinhoud met de rand van een dekglaasje over een hoek van $45^{\circ}$ zo dun mogelijk naar de andere rand van het microscopieglaasje uitgesmeerd. E. Na drogen worden de stalen gekleurd. Door de auteurs wordt standaard een Hemacolor $\AA$-kleuring gebruikt. Afdrukken van verschillende organen kunnen verzameld worden op één microscopieglaasje.

microscopieglaasje. De staalname wordt geïllustreerd in Figuur 1.

\section{Directe uitstrijkjes}

Voor het maken van een kliermaaguitstrijkje wordt de mucosale zijde van de kliermaag rechtstreeks afgedrukt op een microscopieglaasje. Of men kan met een dekglaasje een afkrabsel nemen van de slijmlaag en deze vervolgens uitstrijken op een microscopieglaasje. Ook voor het maken van een mestuitstrijkje wordt met een dekglaasje een afkrabsel genomen van de darminhoud. Met de rand van een dekglaasje over een hoek van $45^{\circ}$ wordt de mestinhoud voorzichtig en zo dun mogelijk naar de andere rand van het microscopieglaasje uitgesmeerd (Figuur 1D).

\section{Kleuringen}

Alvorens te kleuren is het belangrijk de stalen goed te drogen om optimaal celdetail en celadhesie te garanderen. Dit kan door het preparaat te drogen aan de lucht of door het preparaat even op de radiator te leggen. Het gebruik van een bunsenbrander of haardroger wordt echter afgeraden. 


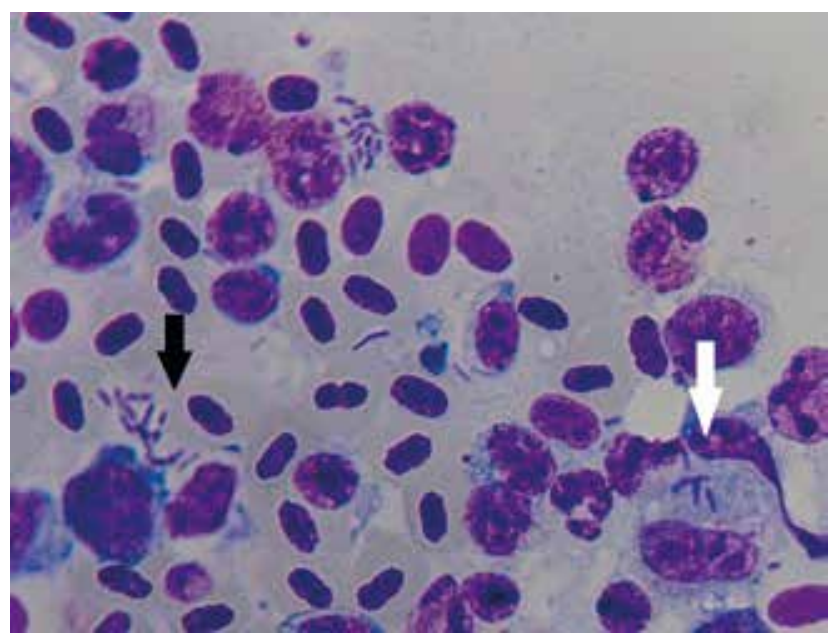

Figuur 2. Sepsisbeeld van de milt van een kanarie. Aanwezigheid van talrijke, aankleurbare, bacteriële staven zowel extracellulair (zwarte pijl) als gefagocyteerd door macrofagen (witte pijl). Gerangschikt van hoge naar lage prevalentie kan differentiaal diagnostisch gedacht worden aan een infectie met Yersinia pseudotuberculosis, Salmonella spp., Escherichia coli en Listeria monocytogenesis. (Hemacolor $\AA$, 1000X).

Voor algemene cytologie wordt gebruik gemaakt van romanowsky-typekleuringen, zoals wright's en may-grünwald-giemsakleuringen. Commerciële benamingen voor deze kleuringen zijn onder andere Diff Quick ${ }^{\circledR}$ en Hemacolor ${ }^{\circledR}$. Bij deze kleuringen wordt de celmorfologie duidelijk doordat basofiele en eosinofiele elementen met elkaar in contrast worden gebracht (Campbell en Ellis, 2007a). Deze kleuringsprocedures zijn eenvoudig, snel $(<20$ seconden) en geven een goede kleurkwaliteit. Door de auteurs wordt

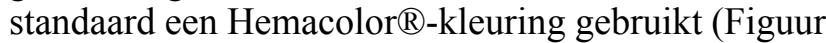
$1 \mathrm{E})$, zo ook in de cytologische illustraties verder in dit artikel. Indien gewenst kunnen ook bijkomende kleuringen gebruikt worden, zoals zhiel-neelsenkleuring voor het aantonen van Mycobacterium spp. of een STAMP-kleuring voor het aantonen van Chlamydia spp.. Het kleuren gebeurt volgens de gebruiksaanwijzing van de specifieke kleuring.

\section{MICROSCOPISCHE BEOORDELING}

Een eerste oriënterend microscopisch onderzoek gebeurt op een lage vergroting (X100). Op deze vergroting kunnen weefsels geïdentificeerd, de cellulariteit van het preparaat beoordeeld en reeds eventuele grote infectieuze pathogenen, bijvoorbeeld Macrorhabdus ornithogaster, schimmelhyfen, herkend worden. Ook wordt bepaald welke zone het beste bekeken wordt met een hoge vergroting (immersie-olie, $\mathrm{X} 1000)$. Interpretaties gebeuren het beste ter hoogte van zones met een monolayer (Dorrestein, 2008; Campbell en Ellis, 2007a).

Op hoge vergroting (immersie-olie, X1000) wordt het preparaat verder in detail beoordeeld. Er wordt onder andere gekeken naar celstructuur, bacteriën of an-

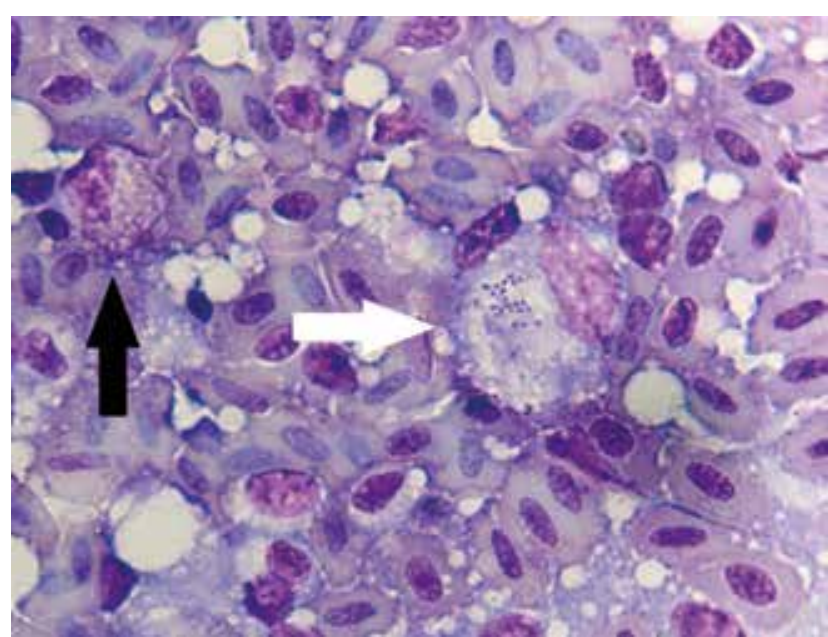

Figuur 3. Enterococcus faecalis-infectie. Septisch ontstekingsbeeld in een afdruk van de lever van een kanarie met infiltratie van heterofielen (zwarte pijl) en macrofagen met gefagocyteerde kokken (witte pijl). (Hemacolor $\left.{ }^{\circledR}, \mathbf{1 0 0 0 X}\right)$.

dere kleine structuren, zoals celinclusies (Dorrestein, 2008; Campbell en Ellis, 2007a). Zowel bij vergroting X100 als X1000 worden telkens verschillende velden geïnspecteerd om te kunnen nagaan wat er zich in het orgaan afspeelt.

Op hoge vergroting worden eerst de orgaancellen bekeken. Er wordt nagegaan of deze cellen een normale of abnormale morfologie vertonen, zoals degeneratie, necrose, inclusies en neoplasie. Ook worden het aantal aanwezige rode bloedcellen en hun morfologie beoordeeld: een verhoogd aantal erytrocyten, een verhoogd aantal immature erytrocyten of de aanwezigheid van inclusies kunnen respectievelijk wijzen op orgaanstuwing, regeneratieve anemie en bloedparasieten (Campbell en Ellis, 2007b).

Een verhoogd aantal leukocyten is indicatief voor inflammatie. De belangrijkste ontstekingscellen bij vogels zijn heterofielen, lymfocyten, plasmacellen en macrofagen (Campbell, 1994a; Mitchell en Johns, 2008). Bij een acuut ontstekingsbeeld wordt een infiltraat van voornamelijk heterofielen (i.e. $>70 \%$ van de ontstekingscellen) waargenomen (Montali, 1988). Ook stressbeeld kan leiden tot heterofieleninfiltratie (Gildersleeve et al., 1987). Aangezien macrofagen snel, i.e. reeds na enkele uren, migreren naar een ontstekingshaard, wordt een gemengd ontstekingsinfiltraat met heterofielen en mononucleaire leukocyten (macrofagen, plasmacellen en lymfocyten) bij vogels het vaakst waargenomen (Montali, 1988). Aldus impliceert een dominant macrofageninfiltraat $(>50 \%)$ niet noodzakelijk een chronische respons, doch kan het bij vogels suggestief zijn voor welbepaalde ziekten, zoals tuberculose, chlamydiose, salmonellose of mycotische infecties (Jortner en Adams, 1971; Awandhiya, 1981). Ook bepaalde neoplastische aandoeningen kunnen leiden tot een verhoogd aantal leukocyten samen met morfologische veranderingen, bijvoorbeeld lymfoma. Aangezien in dit artikel gefocust wordt op infectieziekten, wordt hier niet dieper op ingegaan. 


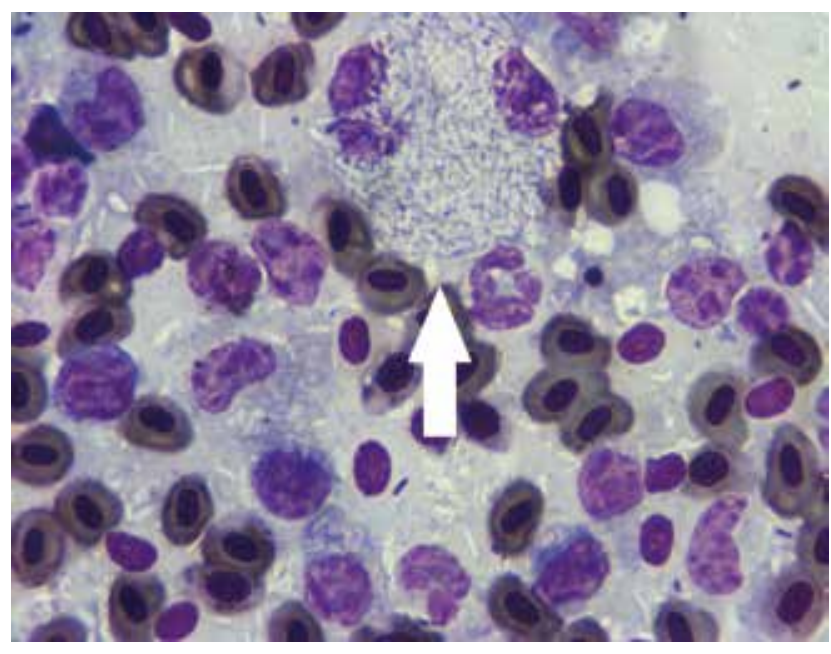

Figuur 4. Mycobacterium-infectie. Septisch ontstekingsbeeld in een afdruk van de milt van een kanarie met aanwezigheid van talrijke, niet-aankleurbare, bacteriele staven zowel extracellulair als gefagocyteerd door macrofagen (witte pijl). (Hemacolor $\left.{ }^{\circledR}, 1000 X\right)$.

Tenslotte wordt het preparaat gecontroleerd op de aanwezigheid van pathogenen, zowel intracellulair als extracellulair, i.e. bacteriën, schimmels, gisten, virale inclusies, parasieten.

\section{CYTOLOGISCHE KARAKTERISTIEKEN VAN INFECTIEUZE PATHOGENEN}

In de periode 2013-2017 werden aan de Afdeling voor Pluimvee, Bijzondere Gezelschapsdieren, Wildlevende Dieren en Proefdieren van de Faculteit Diergeneeskunde (UGent) 224 autopsies uitgevoerd bij zangvogels. De waargenomen klachten waren steeds aspecifiek, namelijk sterfte, al dan niet voorafgegaan door een korte periode van minder eten en dik zitten. Soms werd ook dyspneu of afwijkende mest waargenomen. In $72 \%$ van deze autopsiegevallen kon de definitieve diagnose of waarschijnlijkheidsdiagnose gesteld worden door het aantonen van het etiologische agens met behulp van cytologisch onderzoek. Hierbij dient opgemerkt te worden dat in $42 \%$ van de cases een multifactoriële problematiek werd vastgesteld. Het meest frequent werden co-infecties met Macrorhabdus ornithogaster, atoxoplasmose en/of bacteriele sepsis waargenomen. Hieronder wordt een overzicht gegeven van belangrijke infectieuze aandoeningen waarbij cytologisch onderzoek kan leiden tot een etio-logische diagnose, de cytologische karakteristieken die desgevallend worden waargenomen, alsook de waargenomen prevalentie door de auteurs.

Cytologie geassocieerd met bacteriële aandoeningen

\section{Sepsis}

In $43 \%$ van de gevallen was de sterfte bij zangvogels het gevolg van bacteriële sepsis. Hiervan werd
$23 \%$ veroorzaakt door een infectie met Yersinia pseudotuberculosis, 6\% door Salmonella spp., 5\% door Escherichia coli, 4\% door Mycobacterium spp. en 3\% door een infectie met Enterococcus faecalis. Sporadisch werd sepsis ten gevolge van Listeria monocytogenes (1\%), Pasteurella multocida $(0,5 \%)$ of Staphylococcus spp. $(0,5 \%)$ vastgesteld.

Bij rechtstreekse afdrukken van diverse organen worden na snelle bloedkleuring (Hemacolor $\left.{ }^{\circledR}\right)$ een verhoogd aantal ontstekingscellen, voornamelijk macrofagen en lymfocyten, en een zeer talrijke aanwezigheid van bacteriën waargenomen. Deze bacteriën zijn soms opvallend aanwezig in het cytoplasma van macrofagen (fagocytose). Yersinia pseudotuberculosis, Salmonella spp., Escherichia coli, Pasteurella multocida en Listeria monocytogenesis zijn alle staafjes die sterk basofiel aankleuren na Hemacolor ${ }^{\circledR}$ (Figuur 2). Enterokokken en Stafylokokken zijn op cytologie waar te nemen als basofiele kokvormige bacteriën (Figuur 3). Bij infectie met Mycobacterium spp. worden talrijke ongekleurde aftekeningen van bacteriële staafjes gezien (Figuur 4).

Infecties met Mycobacterium spp., Escherichia coli en Enterococcus faecalis leiden bij zangvogels vaak tot acute sepsis (Eatwell, 2008; Martel en Pasmans, 2013). Op lijkschouwing valt een erge lever- en miltzwelling op. Infecties met Yersinia pseudotuberculosis, Salmonella spp. en Listeria monocytogenesis kennen zowel een acuut als chronisch ziekteverloop (Eatwell, 2008; Martel en Pasmans, 2013). Op autopsie worden speldenkop-grote granulomen of necrosehaarden gevonden bij een vergrote lever en milt. De milt is vaak het ergste aangetast. Op basis van de waargenomen prevalentie van deze infecties, de letsels ter hoogte van de milt en lever (met of zonder granuloomvorming) en de morfologie van de bacteriele populatie op cytologie kan reeds een waarschijnlijkheidsdiagnose worden gesteld. Deze kan vervolgens bevestigd worden door middel van bacteriële cultuur of in het geval van Mycobacterium met een ziehl-neelsenkleuring, eventueel aangevuld met PCRonderzoek. In afwachting van het resultaat kan echter al gestart worden met een gerichte therapie bij de overige vogels.

\section{Campylobacteriose}

Campylobacteriose werd door de auteurs in 6\% van de gevallen vastgesteld. Deze darminfectie, veroorzaakt door Campylobacter jejuni, komt voornamelijk voor bij prachtvinken. Bij verminderde afweer kan een infectie met Campylobacter jejuni leiden tot klinische symptomen, waarbij dik zitten, waterige, gele mest of geelachtige meststaafjes en sterfte worden waargenomen (Eatwell, 2008; Martel en Pasmans, 2008). Op een uitstrijkje van de darminhoud van een levend of vers gestorven dier wordt na Hemacolor ${ }^{\circledR}$ kleuring een homogene populatie van bacteriën met Campylobacter-morfologie waargenomen (komma-, $\mathrm{S}$ - of V-vormig) (Figuur 5). Vaak is de ziekte multi- 


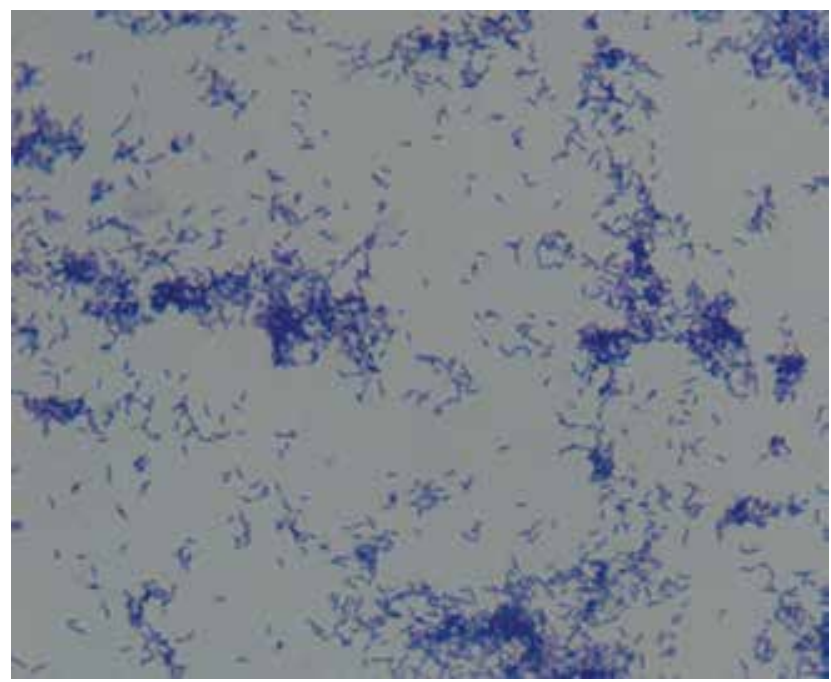

Figuur 5. Campylobacteriose. Uitstrijkje van de darminhoud van een gouldsamadine met een monomorfe populatie van bacteriën met Campylobacter-morfologie: V-vormig of 'meeuwtjes'. (Hemacolor $\left.{ }^{\circledR}, 1000 \mathrm{X}\right)$.

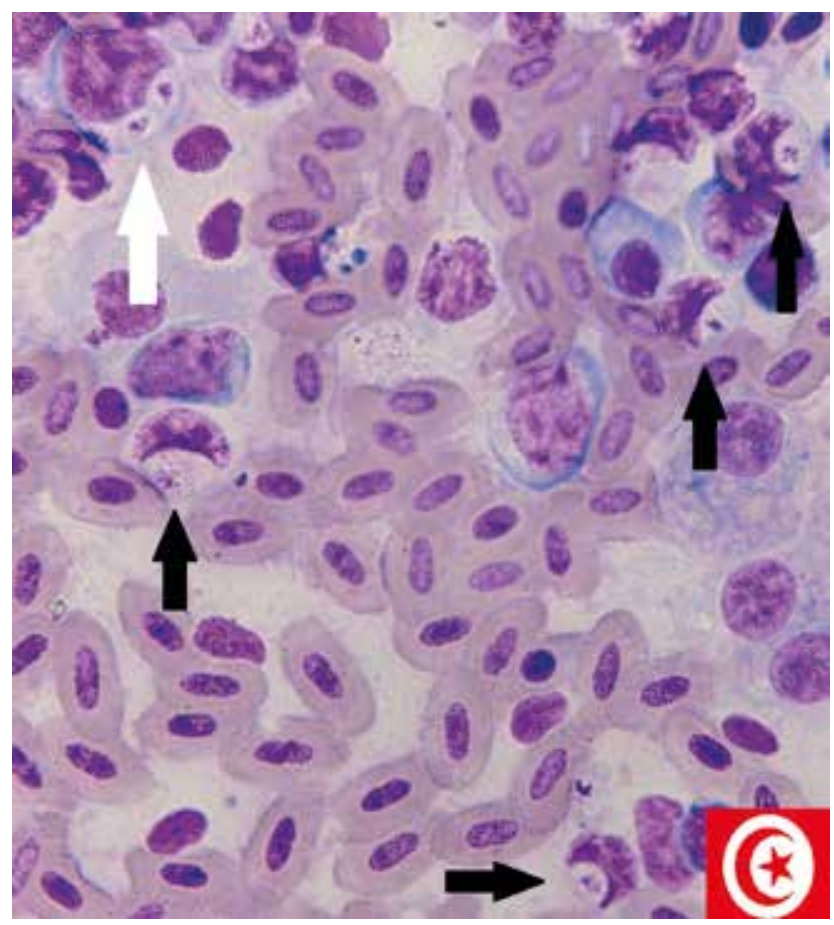

Figuur 6. Atoxoplasmose in een afdruk van de lever van een goudvink. De parasieten zijn te zien als intracytoplasmatische inclusies in mononucleairen. Meestal is er één parasitaire inclusie per mononucleair te zien (zwarte pijlen), te vergelijken met het uitzicht van de vlag van Tunesië (insprong rechts onder). Soms zijn er ook meerdere atoxoplasma-inclusies per aangetaste cel waar te nemen (witte pijl). (Hemacolor ${ }^{\circledR}, \mathbf{1 0 0 0 X}$ ).

factorieel en komt ze samen voor met flagellaten, zoals Cochlosoma en coccidiën. Aldus wordt geadviseerd om ook parasitologisch mestonderzoek uit te voeren. Voor het aantonen van flagellaten dient deze mest zeer vers te zijn.
Cytologie geassocieerd met parasitaire aandoeningen

\section{Atoxoplasmose}

Atoxoplasmose werd door de auteurs in $23 \%$ van de gevallen vastgesteld. De symptomen van klinische atoxoplasmose zijn atypisch en zijn meestal beperkt tot dik zitten en dyspneu. De mortaliteit kan oplopen tot $80 \%$. De ziekte zou veroorzaakt worden door een extra-intestinaal stadium van Isospora spp.. Omdat na de acute fase slechts een beperkt aantal oöcysten uitgescheiden wordt, is het ante mortem moeilijk om de diagnose te stellen (Eatwell, 2008). De diagnose wordt dan ook meestal gesteld op lijkschouwing via cytologisch onderzoek. Long en lever zijn vaak het ergste aangetast. De parasieten zijn te zien als karakteristieke intracytoplasmatische inclusies in mononucleaire cellen. De auteurs vergelijken het cytologisch beeld van de aangetaste mononucleaire cellen met het uitzicht van de Tunesische vlag. De kern van de mononucleaire cel wordt namelijk door de parasiet 'opzij geduwd' en krijgt hierdoor de vorm van een 'krimpende maan'. De kern van de parasiet kan met de ster vergeleken worden (Figuur 6).

\section{Rode vogelmijt}

Een frequent voorkomende ectoparasiet bij zangvogels is Dermanyssus gallinae. Aangezien deze bloedzuigende mijten enkel 's nachts op de dieren parasiteren en zich overdag verstoppen in spleten, worden ze vaak niet door de eigenaar waargenomen. De vogels zijn 's nachts onrustig en een zware infestatie leidt tot anemie en zelfs sterfte. Meestal zijn de parasieten op lijkschouwing niet terug te vinden; indien toch, dan is dit meestal indicatief voor ernstige mijteninfestaties in de volière. Op een afdrukpreparaat van de long van een gestorven dier of op een bloeduitstrijkje van een levend dier, wordt echter een typisch beeld van regeneratieve anemie met verhoogde aanwezigheid $(>10 \%)$ van immature erytrocyten waargenomen (Campbell en Ellis, 2007b). De normale mature erytrocyt bij vogels is ovaal met een centraal gepositioneerde ovale kern. Het cytoplasma kleurt oranje-rozig en de kern is gecondenseerd en donker paars (Campbell, 1994b). Immature rode bloedcellen zijn rond, polychromatisch met een basofiel cytoplasma en een minder condense, rondere kern (Campbell, 1994b; Mitchell en Johns, 2008) (Figuur 7). Een beeld van regeneratieve anemie zonder aanwijsbare oorzaak, bijvoorbeeld gastro-intestinale parasitose, bloedparasieten, etc. werd in $8 \%$ van de aangeboden cases vastgesteld. In deze gevallen wordt geadviseerd om de volière te controleren op de aanwezigheid van rode vogelmijt.

\section{Malaria}

Eenmaal werd door de auteurs een Plasmodium- 


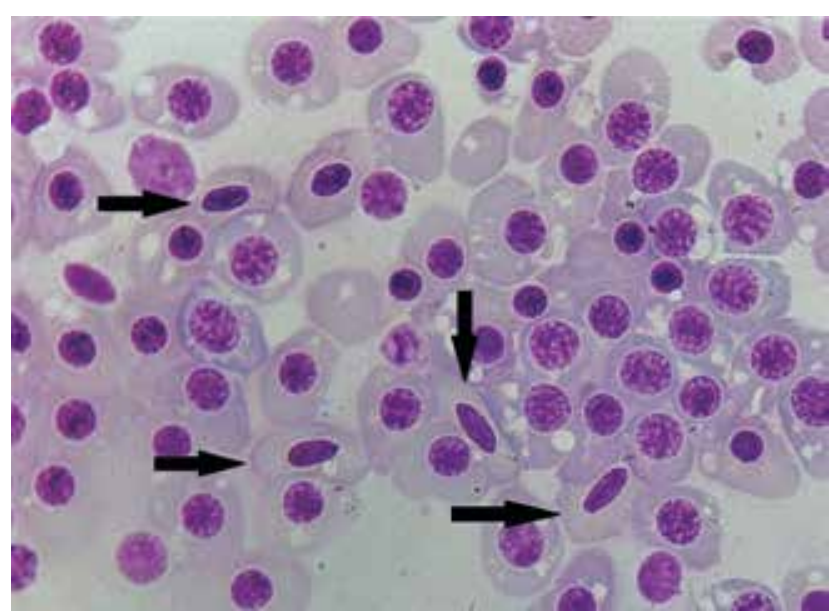

Figuur 7. Regeneratieve anemie. Op deze afdruk van de long van een gouldsamadine zijn slechts enkel mature erytrocyten, i. e. ovaal van vorm en met condense ovale kern, aanwezig (zwarte pijlen). De meeste erytrocyten zijn immatuur, waardoor nog rond van vorm en polychromatisch met basofiele cytoplasma's en minder condenseerde, nog ronde kernen. (Hemacolor $\left.{ }^{\circledR}, 1000 \mathrm{X}\right)$.

infectie vastgesteld $(0,5 \%$ van de gevallen). Op een bloeduitstrijkje van een levend dier of orgaanafdrukje van de long van een gestorven dier worden na snelle bloedkleuring (Hemacolor ${ }^{\circledR}$ ) een beeld van regeneratieve anemie, alsook de parasieten in de bloedcellen gezien (Figuur 8). Gametocyten, schizonten en trofozoïeten van Plasmodium spp. kunnen bij vogels worden gevonden in erytrocyten, trombocyten en leukocyten (Campbell en Ellis, 2007b). Ook kunnen bruine pigment fracties worden waargenomen. Dit is hemozoïne geproduceerd door Plasmodium na digestie van hemoglobine.

\section{Cytologie geassocieerd met mycotische aandoenin- gen}

\section{Macrorhabdus ornithogaster}

Deze vaak voorkomende gistinfectie van de kliermaag werd in $40 \%$ van de gevallen door de auteurs vastgesteld. Een sterke toename van deze gisten in de kliermaag leidt tot het afsluiten van de mucosakliertjes, waardoor de secretie van de $\mathrm{HCl}$ en pepsine wordt geremd. Er worden onverteerde zaden in de feces waargenomen, de algemene conditie van de vogel verslechtert en er treden gewichtsverlies en sterfte op (Davies, 2008; Martel en Pasmans, 2013). Op autopsie wordt een gedilateerde, dikwandige kliermaag met vaak witte mucus opstapeling ter hoogte van het mucosaal oppervlak gezien. De diagnose kan eenvoudig gesteld worden via cytologisch onderzoek van de kliermaag. Op een afkrabsel van de mucosae worden na snelle bloedkleuring bij klinische gevallen grote aantallen gisten vastgesteld. Deze gisten hebben het karakteristiek uitzicht van grote $(>20 \mu \mathrm{m})$ licht basofiele staven gelijkend op hyfen vaak afgelijnd door

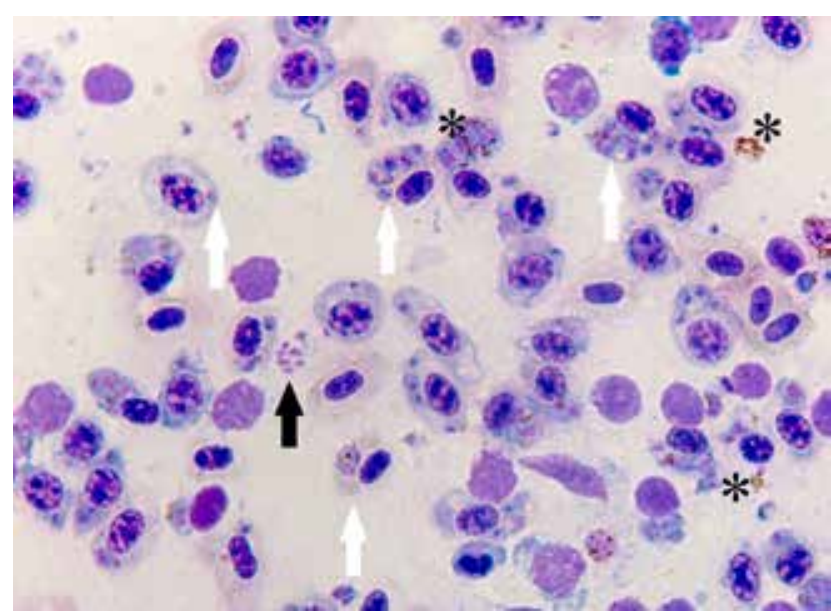

Figuur 8. Plasmodium-infectie. Massale aanwezigheid van immature, ronde, polychromatische erytrocyten als gevolg van een regeneratieve respons in een afdruk van de long van een kanarie. Verschillende ontwikkelingsstadia van Plasmodium zijn talrijk aanwezig zowel in het cytoplasma van de erytrocyten (witte pijlen) als extracellulair (zwarte pijl). Ook zijn er enkele klonters hemozoïne (*) waarneembaar. (Hemacolor $\left.{ }^{\circledR}, 1000 \mathrm{X}\right)$.

middel van een witte rand, het zogenaamde halo-effect (Figuur 9). Bij klinisch duidelijke gevallen kunnen de gisten zodanig sterk vermenigvuldigen, dat zij in grote aantallen het darmkanaal passeren. Desgevallend is er een redelijke kans om de gisten met behulp van een snelle bloedkleuring ook aan te tonen in een fecesuitstrijkje van nog levende dieren.

\section{Aspergillose}

Een Aspergillus fumigatus-infectie bij zangvogels geeft aanleiding tot dyspneu zonder ademgeluiden. Meestal is slechts een beperkt percentage van de dieren aangetast en is er weinig sterfte. Predisponerende factoren zijn een vochtig en warm klimaat, onhygiënische omstandigheden, overbezetting en beschimmeld

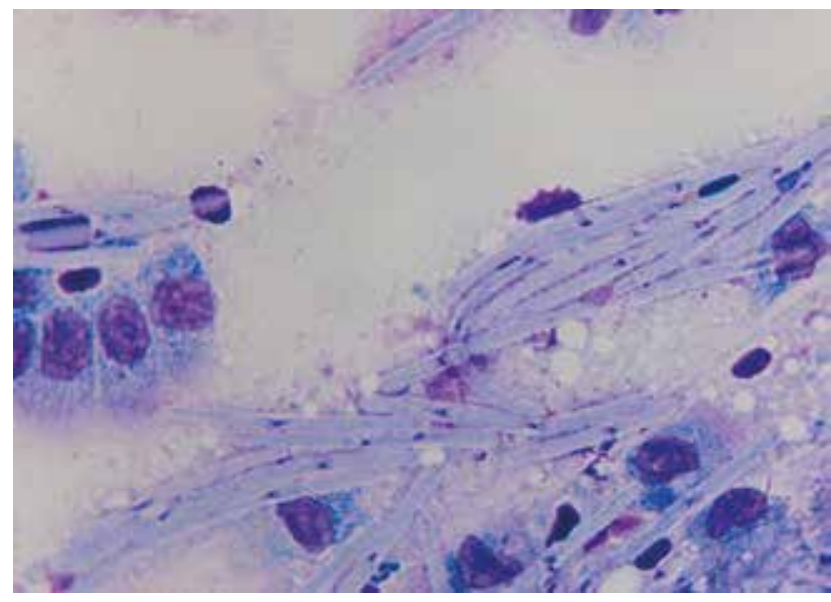

Figuur 9. Macrorhabdus ornithogaster-infectie. Op een afkrabsel van de kliermaagmucosae van een barmsijs worden de gisten als grote, licht basofiele staven gezien. Bemerk ook het halo-effect zichtbaar als een wit aura rondom de gist. (Hemacolor $\left.{ }^{\circledR}, 1000 X\right)$. 


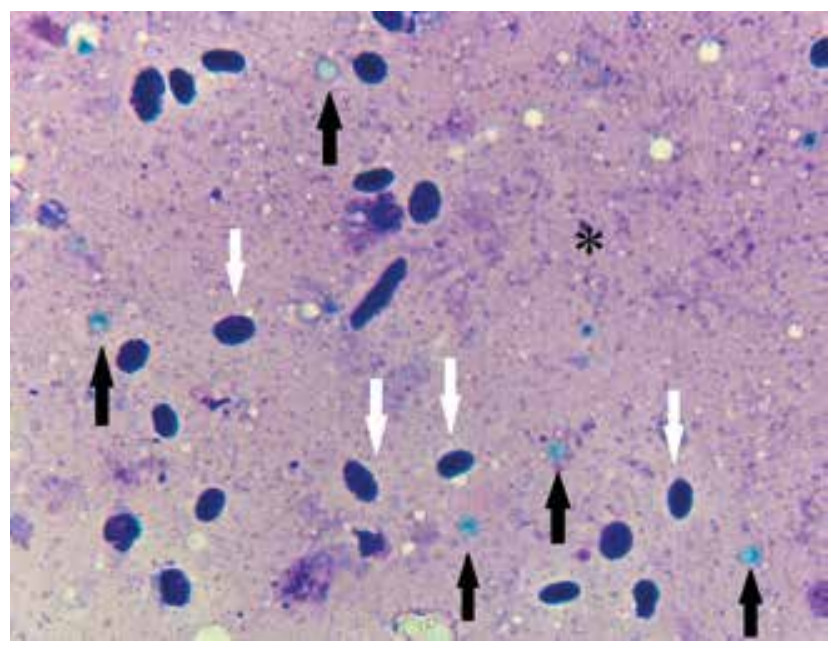

Figuur 10. Aspergillose. Aanwezigheid van talrijke schimmelsporen (zwarte pijlen) in de long van een zebravink met oedeem (*) en gelyseerde erytrocyten (witte pijlen). (Hemacolor $\left.{ }^{\circledR}, 1000 \mathrm{X}\right)$.

voeder of beschimmeld neststrooisel (Macwhirter, 1994; Martel en Pasmans, 2013). De diagnose is in vivo moeilijk te stellen en gebeurt meestal pas na lijkschouwing. Een karakteristiek letsel is granuloomvorming ter hoogte van de luchtwegen (aspergillomen). Op cytologisch onderzoek kunnen de schimmelsporen als contrasterende basofiele bolletjes worden waargenomen op afdrukpreparaten van de longen en/ of luchtzakken (Figuur 10). Schimmelhyfen worden vrijwel nooit aangetroffen op cytologisch onderzoek. Aspergillose komt zelden voor bij graaneters, zoals kanaries en prachtvinken. Fruiteters en insecteneters worden vaker getroffen. Door de auteurs werd de diagnose van aspergillose in $4 \%$ van de gevallen vastgesteld.

\section{Candida}

Zowel kropcandidiase als darmcandidiase komt voor. Dieren met kropcandidiase vertonen een verminderde voederopname, braken, kropovervulling en eventueel diarree en dyspneu. Darmcandidiase wordt gekenmerkt door dik zitten, een verminderde voederopname, half vloeibare feces, maar meestal weinig sterfte. De aandoening komt voornamelijk voor bij fruit- en honingetende vogels. Daarnaast wordt de aandoening ook vastgesteld bij insecteneters, prachtvinken en recessief witte kanaries. Predisponerend zijn een onevenwichtige voeding, immunosuppressie, antibioticabehandeling en in het geval van recessief witte kanaries een vitamine A-tekort (Martel en Pasmans, 2013). Deze vogels zijn namelijk deficiënt voor de aanmaak van vitamine A uit caroteen. De diagnose kan gemakkelijk gesteld worden door het aantonen van de gisten met rechtstreekse snelle bloedkleuring (Hemacolor $($ ) van uitstrijkjes van de darminhoud of krop (Figuur 11). Deze ovale gist vertoont knopvor-

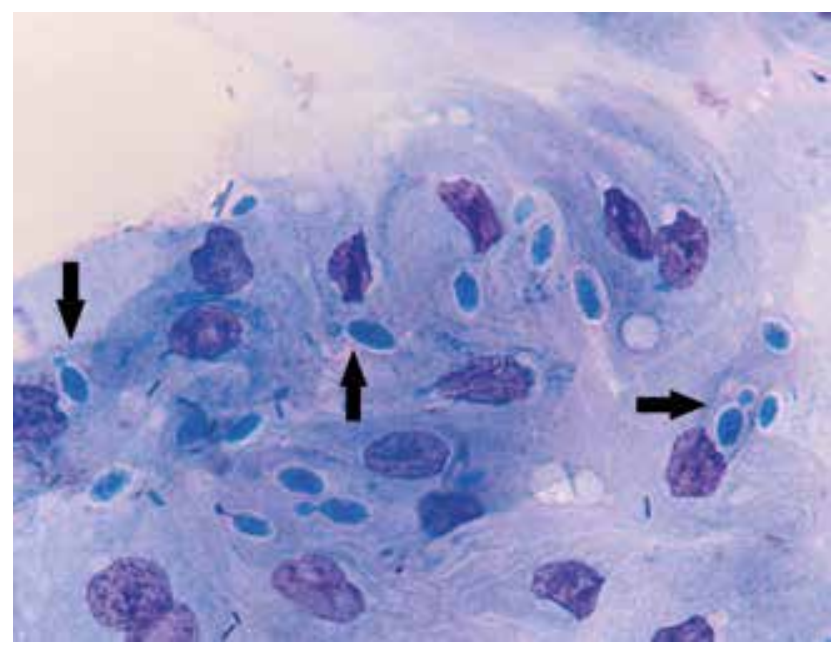

Figuur 11. Candidiase. Aanwezigheid van talrijke ovale gisten op een uitstrijkje van de darminhoud van een kanarie. Bemerk de typische knopvorming (zwarte pijlen) alsook het halo-effect, zichtbaar als een wit aura rondom de gist. (Hemacolor $\left.{ }^{\circledR}, 1000 \mathrm{X}\right)$.

ming en vaak is ook een "halo" waar te nemen. Op autopsie werd candidiase door de auteurs in $2 \%$ van de gevallen waargenomen.

\section{CONCLUSIE}

Op basis van de autopsieresultaten uitgevoerd op zangvogels in de periode 2013-2017 blijkt cytologisch onderzoek na post-mortemonderzoek van onschatbare waarde. In $72 \%$ van de ingezonden cases kon met behulp van cytologie een etiologische diagnose of waarschijnlijkheidsdiagnose gesteld worden. Met behulp van de cytologische illustraties beschreven in dit overzicht kan de clinicus zich zelf bekwamen in het aflezen van cytologische preparaten om een snelle, aanvullende diagnose te bekomen wanneer hij of zij geconfronteerd wordt met groepssterfte. Dit met het oog op het starten van een gerichte therapie, in afwachting van (indien nodig) de resultaten van verder bacteriologisch, histologisch en/of PCR-onderzoek.

\section{REFERENTIES}

Awandhiya R.P., Vegad J.L., Kolte G.N. (1981). A microscopic study of increased vascular permeability and leukocyte emigration in the chicken wing web. Research in Veterinary Science 31, 231-235.

Campbell T.W. (1994a). Cytology. In: Ritchie B.W., Harrison G.J. and Harrison L.J. (editors). Avian Medicine: Principles and Application. HBD International, Delray Beach, Florida, USA, pp.199-222.

Campbell T.W. (1994b). Hematology. In: Ritchie B.W., Harrison G.J. and Harrison L.J. (editors). Avian Medicine: Principles and Application. HBD International, Delray Beach, Florida, USA, pp.176-198.

Campbell T. W. en Ellis C. K. (2007a). Comparative cyto- 
logy. In: Campbell T.W. and Ellis K.E. (editors). Avian and Exotic Animal Hematology and Cytology. Third edition, Blackwell Publishing, Oxford, UK, pp. 139-217.

Campbell T. W. en Ellis C. K. (2007b). Hematology of birds. In: Campbell T.W. and Ellis K.E. (editors). Avian and Exotic Animal Hematology and Cytology. Third edition, Blackwell Publishing, Oxford, UK, pp. 3-50.

Davies R.R. (2008). Passerine birds: going light. In: Chitty J. and Lierz M. (editors). BSAVA manual of Raptors, Pigeons and Passerine Birds. British Small Animal Veterinary Association, Gloucester, UK, pp. 365-369.

Dorrestein G.M. (2008). Clinical pathology and post-mortem examination. In: Chitty J. and Lierz M. (editors). BSAVA manual of Raptors, Pigeons and Passerine Birds. British Small Animal Veterinary Association, Gloucester, UK, pp.48-61.

Eatwell K. (2008). Passerine birds: investigation of flock mortality/morbidity. In: Chitty J. and Lierz M. (editors). BSAVA manual of Raptors, Pigeons and Passerine Birds. British Small Animal Veterinary Association, Gloucester, UK, pp. 370-376.

Gildersleeve R.P., Satterlee D.G., Scott T.R., McRee D.I., Parkhurst C.R. en Cook M.E. (1987). Hematology of
Japanese quail selected for high or low serum corticosterone responses to complex stressors. Comparative Biochemistry and Physiology 86, 569-573.

Jortner B.S., Adams W.R. (1971). Turpentine-induced inflammation in the chicken: A light and electronmicroscopy study with emphasis on the macrophage, epithelioid cell, and multinucleated giant cell reaction. Avian Diseases 15, 533-550.

Macwhirter P. (1994). Passeriformes. In: Ritchie B.W., Harrison G.J. and Harrison L.J. (editors). Avian Medicine: Principles and Application. HBD International, Delray Beach, Florida, USA, pp.1172-1199.

Martel A., Pasmans F. (2013). Zangvogels. In: Goudswaard J., Schrooyen J., Franse-Blok M.B., et al. (editors). Diergeneeskundig Memorandum. Bijzondere Gezelschapsdieren. DM, Boxtel, Nederland, pp. 116-128.

Mitchell E.B., Johns J. (2008). Avian hematology and related disorders. Veterinary Clinics Exotic Animal Practice $11,501-522$

Montali R.J. (1988). Comparative pathology of inflammation in the higher vertebrates (reptiles, birds, and mammals). Journal of Comparative Pathology 99, 1-26.

We kennen en respecteren het gezegde dat je een gekregen paard niet in de muil mag kijken. Een cadeautje mag je niet te kritisch beoordelen. Maar wat als je iets aftands kreeg? Ook 'aftands' stamt uit de paardenhandel. Het is afgeleid van de tandwisseling en meer nog de slijtage die duidt op een oude knol: die is 'aftands'. 